\title{
Optimization of milk-clotting enzyme production by Bacillus amyloliquefaciens SP1 isolated from apple rhizosphere
}

\author{
Shiwani Guleria ${ }^{*}$, Abhishek Walia ${ }^{2}$, Anjali Chauhan ${ }^{3}$ and C. K. Shirkot ${ }^{3}$
}

\begin{abstract}
Background: Present study aims to isolate and optimize fermentation conditions of milk-clotting enzyme producing rhizobacteria Bacillus amyloliquefaciens SP1.

Results: A bacterium producing an extracellular milk-clotting enzyme (MCE) was isolated from the rhizosphere of the planted population of apple trees growing at Distt. Chamba of Himachal Pradesh, India. According to morphological, physiological, biochemical, and molecular characterization, isolate was identified as B. amyloliquefaciens. Single-factor testing was used to study the optimum physical conditions and nutritional parameters for production of the MCE per proteolysis activity which insures its usefulness as new source of milk coagulant for cheese making. The optimum conditions for production of the milk-clotting enzyme were: temperature, $30^{\circ} \mathrm{C}$; inoculum size, $1 \%$; and initial pH of the medium, 6.0. The maximum milk-clotting activity and milk-clotting activity per proteolysis activity were found using soyabean as nitrogen source and sucrose as carbon source.

Conclusion: These optimized conditions resulted in a 1.9-fold increase in production of the milk-clotting enzyme. This study reported a plant growth promoting rhizobacteria, i.e., B. amyloliquefaciens as source of milk-clotting enzyme which has potential as a calf rennet substitute.
\end{abstract}

Keywords: B. amyloliquefaciens, Milk-clotting enzyme, Protease, Optimization

\section{Background}

The quality of cheese is significantly dependent on the type of milk-clotting enzyme, which is important in the process of milk coagulation and cheese maturation (Kumar et al. 2005). Calf rennet, one of the important enzymes, is traditionally used for cheese making all over world, but due to shortage of animal rennet supply, and ever increase of cheese production and consumption have stimulated the research for milk-clotting enzyme (MCE) from alternative sources to be used as calf rennet substitutes (Nouani et al. 2011).

However, various animals, plants, and microbial proteases have been suggested as milk coagulants (Zhang et al. 2011), but still attention has been focused on

\footnotetext{
*Correspondence: shg1988@gmail.com

1 Department of Microbiology, Kurukshetra University, Kurukshetra, Haryana, India

Full list of author information is available at the end of the article
}

production of milk-clotting enzymes from microbial sources (Silveira et al. 2005; Wu et al. 2013) due to their rapid growth, relative inexpensive growth substrate, and diverse properties. Microbial rennet-like milkclotting enzymes are aspartic proteases that catalyze milk coagulation. Although, there are some shortcomings when compared with traditional calf rennet, even then microbial rennet has been accepted in markets of several countries. In the US alone, about $60 \%$ of the cheese is manufactured using fungal enzymes (Hashem 2000). Many microorganisms that produce milk-clotting enzymes, i.e., Rhizomucor miehei, Aspergillus oryzae, Enthothia parasitica, and Aspergillus flavo furcatis, are widely used (He et al. 2011; Li et al. 2012; Alecrim et al. 2015). In the case of microbial rennets from Mucor sp., none of the available reports contains any indication that the use of the enzyme in cheese manufacture is unsafe (Tubesha and Delaimy 2003). 
Bacillus sp. is one of the most investigated microbial groups, because they can produce varieties of biotechnological interesting substances. The capacity of Bacillus strains to produce and secrete large quantities of extracellular enzymes, including amylase, protease, and cellulases, has led them to be among the most important industrial enzyme producers. In the present study also, the production of milk-clotting enzyme from $B$. amyloliquefaciens has been reported. It is widely known that microbial enzyme production is greatly influenced by many factors, especially medium composition and cultivation conditions. Therefore, work on the optimization of parameters for milk-clotting enzyme is conducted using the "one-factor-at-a time" technique to find out high MCA with proteolytic activity. Because, an adequate substitute must have intense milk-clotting and proteolytic activities (PA) to minimize dissolution of the clot.

Bacillus amyloliquifaciens, which can produce milkclotting enzyme, has been isolated from apple rhizosphere from northern Himalayas. The objective of present work is to investigate the possibility of use of $B$. amyloliquifaciens for the efficient production of rennin, such as enzymes. For cheese making, the present work was undertaken to investigate the pattern of milk-clotting and proteolytic activities of B. amyloliquifaciens in extracellular bacterial enzyme preparations under different conditions of culturing.

\section{Methods}

\section{Sample collection}

Rhizobacteria were isolated from the rhizosphere of the planted population of apple trees growing at four different locations, viz., Chamba, Shimla, Kinnaur, and Kullu of Himachal Pradesh, India. Five sites within each location and randomly ten trees from different apple orchards of each site were selected for sample collection. Samples were immediately stored at $4{ }^{\circ} \mathrm{C}$ in plastic bags loosely tied to ensure sufficient aeration and to prevent moisture loss until assaying of bacterial community structure.

\section{Strain isolation}

One gram of each soil sample was serially diluted. Aliquots of $100 \mu \mathrm{l}$ diluted soil samples were spread on screening plates with casein agar medium composed of $0.25 \%$ yeast extract, $0.5 \%$ casein, $0.1 \%$ Glucose, and $1.5 \%$ agar powder. The plates were incubated at $37{ }^{\circ} \mathrm{C}$ and observed daily for signs of clearing of agar around the colonies during incubation. The formation of clear zone around colony margin was picked as enzyme producers. The bacteria were maintained at $4{ }^{\circ} \mathrm{C}$ on the solid medium, and they were also stored in $15 \%$ glycerol at $-20{ }^{\circ} \mathrm{C}$ as cryoprotectant.

\section{Morphological characterization}

Morphological characteristics of isolates, including colony morphology, Gram's reaction, cell shape, and presence of spores, were investigated (Sneath 1994).

\section{Metabolic fingerprinting}

Metabolic fingerprinting was done using Bergey's manual of systematic bacteriology (Sneath 1994) and TM commercial kits, i.e., KB009 Hi carbohydrate kit (HiMedia, India).

\section{Molecular taxonomic characterization}

Bacterial isolate was grown in nutrient broth at $35{ }^{\circ} \mathrm{C}$ overnight. Bacterial cells were harvested by centrifugation at $5000 \times g$ for $5 \mathrm{~min}$, and DNA was isolated from these bacterial cells using the conventional method (Sambrook et al. 1989). The isolated DNA was finally suspended in $100 \mu \mathrm{l}$ of elution buffer and quantified on $1 \%$ agarose gel. The total genomic DNA was kept at $-20{ }^{\circ} \mathrm{C}$ before use (Sambrook and Russel 2001). Species level identification of strain was conducted by $16 \mathrm{~S}$ rDNA sequence comparison. PCR reaction was carried out in $20 \mu \mathrm{l}$ reaction containing $50 \mathrm{ng}$ of template DNA, 20 pmol of each primer fC1 (5'-GCAAGTCGAGCGGACAGATGGGAGC-3') and reverse primer rC2 (5'-AACTCTCGTGGTGTGACGGGCGGTG-3'), $0.2 \mathrm{mM}$ dNTPs, and $1 \mathrm{U}$ Taq polymerase (Genei Bangalore) in $1 \times$ PCR buffer. Reaction was cycled 35 times as $94{ }^{\circ} \mathrm{C}$ for $1 \mathrm{~min}, 50^{\circ} \mathrm{C}$ for $30 \mathrm{~s}$, and $72^{\circ} \mathrm{C}$ for $90 \mathrm{~s}$, followed by final extension at $72{ }^{\circ} \mathrm{C}$ for $10 \mathrm{~min}$. The PCR products were analyzed on $1 \%$ agarose gel in $1 \times$ TAE buffer, run at $100 \mathrm{~V}$ for $1 \mathrm{~h}$. Gels were stained with ethidium bromide and photographed. Amplified PCR products were eluted from the gel using gel extraction kit (Real genomic (Hi Yield0 TM Gel/PCR DNA Extraction Kit), and eluted fragment was then sequenced (Xcleris, India) using PCR primers.

\section{Sequence analysis}

The sequence was aligned with corresponding sequences of $16 \mathrm{~S}$ rDNA from the database using BLAST (Altschul et al. 1997). Multiple alignments were generated by the MULTALIN program (Corpet 1988). Phylogenetic tree was constructed with the help of ClustalW (Higgins et al. 1994). Tree was viewed with the help of TreeView (Page 1996).

\section{Liquid-state fermentation (LSF)}

Liquid-state fermentation was carried out in Erlenmeyer flasks $(250 \mathrm{ml}$ ) containing $25 \mathrm{ml}$ of casein medium supplemented with skim milk autoclaved at 15 psi pressure for $20 \mathrm{~min}$, and cooled and inoculated with $0.5 \mathrm{ml}$ 
bacterial suspension (OD 1.0 at $540 \mathrm{~nm}$ ) (Walia et al. 2013). After mixing, the flasks were incubated at $35{ }^{\circ} \mathrm{C}$ for 3 days. The culture supernatant was obtained following centrifugation at $12,000 \mathrm{rpm}$ for $20 \mathrm{~min}$ at $4{ }^{\circ} \mathrm{C}$. The supernatant was used as the crude enzyme for assay of milk-clotting and proteolytic activities.

To investigate the factors affecting MCE per protease production, the cultivation was carried out in the medium and conditions indicated above except that the factors were varied by one-factor-at-a-time fashion.

\section{Assay for milk-clotting activity}

Milk-clotting activity (MCA) was determined according to the method of Arima et al. (1970) and expressed in terms of Soxhlet units (SU). One SU is defined as the amount of enzyme which clots $1 \mathrm{ml}$ of a solution containing $0.1 \mathrm{~g}$ skim milk powder and $0.00111 \mathrm{~g}$ calcium chlorides in $40 \mathrm{~min}$ at $35^{\circ} \mathrm{C}$. In brief, $0.5 \mathrm{ml}$ of tested materials was added to a test tube containing $5 \mathrm{ml}$ of reconstituted skim milk solution $(10 \mathrm{~g}$ dry skim milk/100 ml, $0.01 \mathrm{M}$ $\mathrm{CaCl}_{2}$ ) pre-incubated at $35^{\circ} \mathrm{C}$ for $5 \mathrm{~min}$. The mixture was mixed well, and the clotting time $T$ (s), the time period starting from the addition of test material to the first appearance of clots of milk solution, was recorded and the clotting activity was calculated using the following formula: $\mathrm{SU}=2400 \times 5 \times \mathrm{D} / \mathrm{T} \times 0.5 ; T=$ clotting time (s); $D=$ Dilution of test material.

\section{Protease assay}

Protease activity (PA) was measured according to the method described by Sigma with slight modifications (Enyard 2008). One milliliter of culture filtrate was added with $5 \mathrm{ml}$ of $0.5 \%(\mathrm{w} / \mathrm{v})$ casein solution in tris$\mathrm{HCl}$ buffer of $\mathrm{pH} 7.0$ and incubated for $5 \mathrm{~min}$ at $50{ }^{\circ} \mathrm{C}$. The reaction mixture was stopped by addition of $5 \mathrm{ml}$ of trichloroacetic acid $(110 \mathrm{mM})$. The reaction mixture was centrifuged at 10,000 rpm for $5 \mathrm{~min}$ and to $2 \mathrm{ml}$ of supernatant $5 \mathrm{ml}$ of $500 \mathrm{mM} \mathrm{Na}_{2} \mathrm{CO}_{3}$ was added followed by $1 \mathrm{ml}$ Folins-Ciocalteau reagent. The amount of tyrosine released was determined spectrophotometrically at $660 \mathrm{~nm}$ against the enzyme blank.

One unit of protease activity was equivalent to the amount of enzyme that required releasing $1 \mu \mathrm{g}$ of tyrosine $/ \mathrm{ml} / \mathrm{min}$ under the standard assay conditions.

\section{Results}

\section{Isolation and screening of rhizobacteria}

A total of 76 proteolytic bacteria were isolated from rhizosphere (RS) and endorhizosphere (ER) of apple trees of four different locations of Himachal Pradesh viz. Chamba, Shimla, Kinnaur, and Kullu. Forty colonies from Chamba, 15 colonies from Shimla, 14 producers from Kinnaur, and 7 isolates were from Kullu, respectively.
Among all, strain SP1, which was isolated from rhizosphere of the planted population of apple trees growing at District Chamba of Himachal Pradesh, India, showed maximum clear zone on casein agar plates after $48 \mathrm{~h}$ of incubation. In liquid fermentation, strain SP1 produced proteolytic enzyme and considerable amount of milkclotting enzyme (data not shown).

\section{Characterization of $B$. amyloliquifaciens \\ Phenotypic and metabolic characteristics of $B$. \\ amyloliquifaciens}

The strain SP1 was characterized initially according to morphological, physiological, and biochemical characteristics (Table 1). The isolated colonies on casein agar medium after $48 \mathrm{~h}$ of incubation were cream colour, irregular, undulate, wrinkled, and $0.5-0.8 \mathrm{~mm}$ in diameter. The morphological characteristics of the strain were as follows: the cells were Gram positive, rods, spore forming, and motile. The rods occurred singly or in chains.

The physiological and biochemical characteristics of the isolated strain SP1 are given in Table 1. The isolate is an aerobic and a catalase producing strain. The isolate tested positive for gelatine liquefaction and starch hydrolysis. The strain was positive for esculin hydrolysis and could utilize a wide array of carbohydrates [assessed using a KB009 Hi366 carbohydrate TM Kit (HiMedia, India)], including xylose, lactose, galactose, raffinose, trehalose, L-arabinose, glycerol, sorbitol, mannitol, erythritol, and melezitose as sole carbon source.

\section{Phylogenetic analysis of $B$. amyloliquifaciens}

Universal primers were used successfully to amplify $16 \mathrm{~S}$ rDNA from bacterial isolate SP1, yielding an amplicon of the expected size, i.e., $1375 \mathrm{bp}$. The sequence of $16 \mathrm{~S}$ rDNA from strain SP1 was then analyzed using the BLASTn analysis (http://www.ncbi.nlm.nih.gov/blast), and was found to have $100 \%$ homology with several $B$. amyloliquifaciens reported from different parts of the world. The $16 \mathrm{~S}$ rDNA sequence of strain SP1 was also compared with the corresponding sequences of different $B$. amyloliquifaciens reported from different parts of the world. Sequence analysis revealed that SP1 belongs to B. amyloliquifaciens, as it showed maximum homology (92 \%) with B. amyloliquifaciens (accession no. Eu855195) (Fig. 1).

To trace out the evolutionary patterns of the test isolate and to determine the relationship with other selected sequences at NCBI, a phylogenetic tree was also constructed using the neighbor-joining $(\mathrm{J})$ method of mathematical averages (UPGMA) with quite high statistical support by the bootstrap estimates for 1,000 replications. The resulting phylogenetic tree (Fig. 1) also 
Table 1 Differential phenotypic and metabolic characteristics of the B. amyloliquifaciens

\begin{tabular}{|c|c|}
\hline Characteristics & Bacillus amyloliquifaciens \\
\hline Colony morphology & Irregular undulate wrinkled \\
\hline Gram character & + \\
\hline Sporulating & + \\
\hline Motile & + \\
\hline Gelatin liquefaction & + \\
\hline Starch hydrolysis & + \\
\hline Catalase & + \\
\hline Cellulolytic & - \\
\hline Oxidase & - \\
\hline Urease production & - \\
\hline $\mathrm{H}_{2} \mathrm{~S}$ production & - \\
\hline \multicolumn{2}{|l|}{ Utilization of } \\
\hline Lactose & + \\
\hline Xylose & + \\
\hline Maltose & - \\
\hline Fructose & - \\
\hline Dextrose & - \\
\hline Galactose & + \\
\hline Raffinose & + \\
\hline Trehalose & + \\
\hline Melibiose & - \\
\hline Sucrose & - \\
\hline L-Arabinose & + \\
\hline Mannose & - \\
\hline Inulin & - \\
\hline Sodium gluconate & - \\
\hline Glycerol & + \\
\hline Salicin & - \\
\hline Dulcitol & - \\
\hline Inositol & - \\
\hline Sorbitol & + \\
\hline Mannitol & + \\
\hline Arabitol & - \\
\hline Erythritol & + \\
\hline a-Methyl D-glucoside & - \\
\hline Rhamnose & - \\
\hline Cellobiose & - \\
\hline Melezitose & + \\
\hline a-Methyl D-mannoside & - \\
\hline Xylitol & - \\
\hline ONPG & - \\
\hline Esculin hydrolysis & + \\
\hline D-Arabinose & - \\
\hline Citrate utilization & - \\
\hline Malonate utilization & - \\
\hline
\end{tabular}

verified SP1 as B. amyloliquifaciens clustered closely with B. amyloliquifaciens with high boot-strap value (92\%). The 16S rDNA sequence of the strain has been deposited in the GenBank database under accession number KF923792. Based on above morphological, biochemical, and molecular characterization, the strain SP1 was identified as B. amyloliquifaciens.

\section{Effects of carbon sources on the production of milk-clotting activity}

To determine the impact of carbon sources on the production of MCA by B. amyloliquifaciens, the bacteria were cultivated in the casein broth medium except that the carbon source, i.e., glucose was replaced with the sucrose, maltose, lactose, starch, and cellulose in the same amount. As shown in Fig. 2, when the lactose, sucrose, starch, and cellulose were used as the carbon source, low MCA was detected in the medium. In contrast, sucrose $(75 \mathrm{SU} / \mathrm{ml})$ and glucose $(80 \mathrm{SU} / \mathrm{ml})$ produced high levels of MCA. However, maximum proteolytic activity $(2050 \mu \mathrm{g} / \mathrm{ml} / \mathrm{min})$ was observed when maltose was in production medium and lowest, i.e., $1630 \mu \mathrm{g} / \mathrm{ml} / \mathrm{min}$ and $1740 \mu \mathrm{g} / \mathrm{ml} / \mathrm{min}$ protease activity was observed in the case of glucose and sucrose. It is noticed that although using glucose as a carbon source produced higher MCA than using sucrose, the proteolytic activity was also significantly higher when glucose was used instead of sucrose. The ratio of MCA/PA is higher for sucrose than for glucose. Therefore, sucrose appears to be a more suitable carbon source for the production of MCE by $B$. amyloliquifaciens SP1.

\section{Effects of nitrogen sources on the production of milk-clotting activity}

To investigate the effect of nitrogen sources on the MCE production, experiments were carried out with different organic and inorganic nitrogen sources, namely casein, soyabean, tryptone, peptone, gelatin, yeast extract, urea, and ammonium chloride $\left(\mathrm{NH}_{4} \mathrm{Cl}\right)$. The medium with the presence or absence of caesin was further supplemented with various nitrogen sources at $0.5 \%$ level. The bacteria were incubated at $37^{\circ} \mathrm{C}$ with shaking at $120 \mathrm{rpm}$ for $48 \mathrm{~h}$. The results are shown in Fig. 3. It appears that the presence of inorganic nitrogen sources (urea and ammonium chloride) is not critical for the production of milk-clotting activities by $B$. amyloliquifaciens, but organic nitrogen sources (casein, soyabean, tryptone, peptone, and yeast extract) favored high enzyme yield. Similarly, maximum protease activity $(1760 \mu \mathrm{g} / \mathrm{ml} / \mathrm{min})$ 


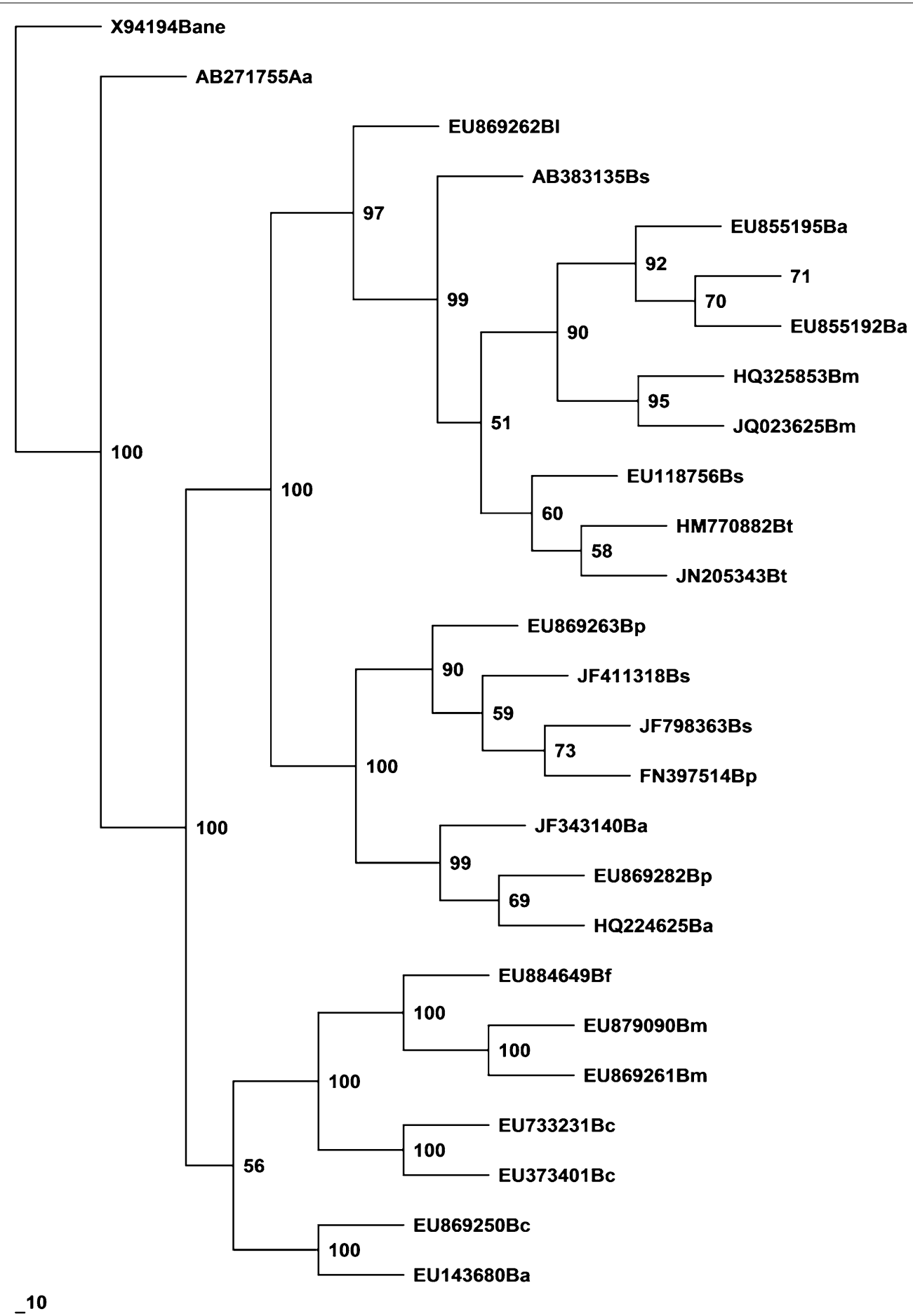

Fig. 1 Phylogenetic tree based on 165 rDNA sequences, drawn using the neighbor-joining method with evolutionary distances computed using Kimura's two parameter method, showing the relationship of Bacillus amyloliquifaciens with published sequences of related genera

observed when gelatin was used as nitrogen source. In the present study, it was revealed that soyabean as nitrogen source produced maximum MCA $(96 \mathrm{SU} / \mathrm{ml})$ and MCA per PA.
Time course of milk-clotting activity produced

Figure 4 shows the time course of patterns of MCE and protease production for B. amyloliquifaciens at $37{ }^{\circ} \mathrm{C}$, the highest MCA (115 SU/ml) with minimum 


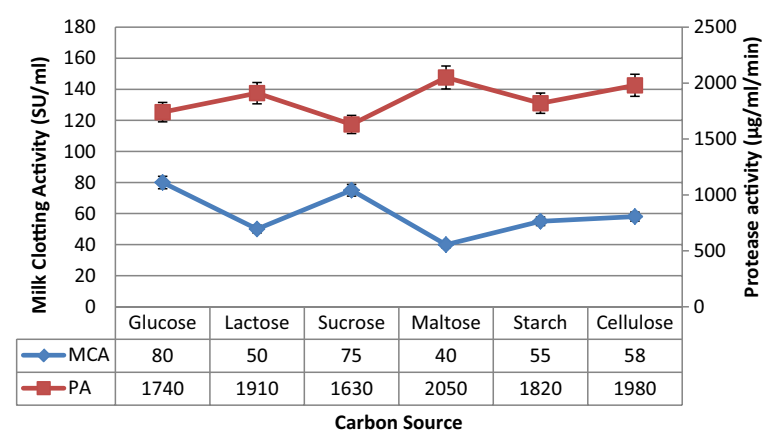

Fig. 2 Milk-clotting activity produced by Bacillus amyloliquifaciens affected by different carbon sources

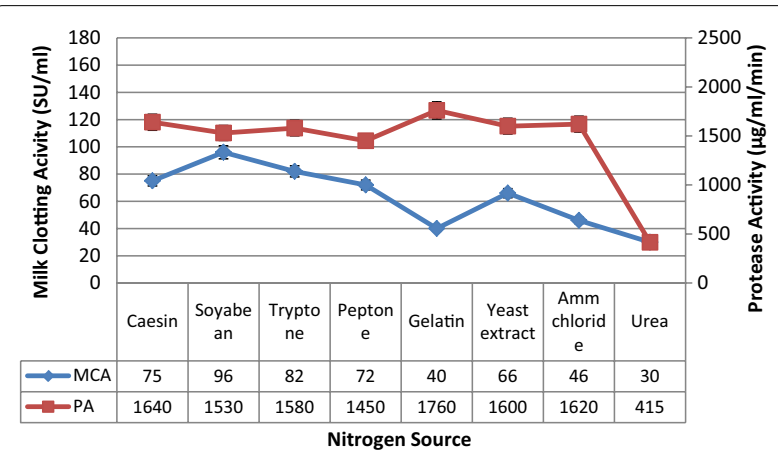

Fig. 3 Milk-clotting activity produced by Bacillus amyloliquifaciens affected by different nitrogen sources

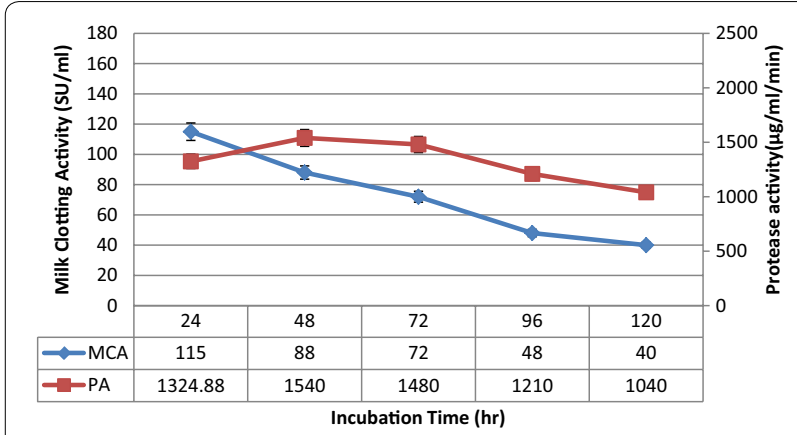

Fig. 4 Time course of milk-clotting activities produced by Bacillus amyloliquifaciens

proteolytic activity of $1324.88 \mu \mathrm{g} / \mathrm{ml} / \mathrm{min}$ was reached after the bacteria were cultivated for $24 \mathrm{~h}$, but significantly reduced MCA was observed in the culture filtrate with extended cultivation time. However, protease activity was increased upto $48 \mathrm{~h}(1540 \mu \mathrm{g} / \mathrm{ml} / \mathrm{min})$, thereafter decreased.

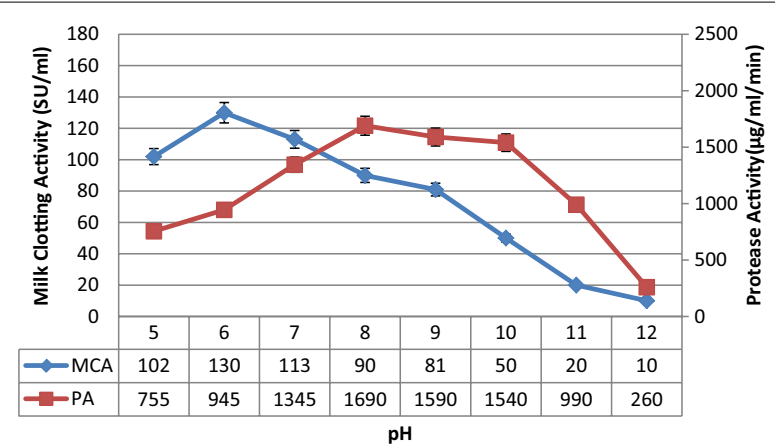

Fig. 5 Milk-clotting activity produced by Bacillus amyloliquifaciens affected by the initial $\mathrm{pH}$ of medium in $24 \mathrm{~h}$ of cultivation

\section{Production of milk-clotting activity affected by the initial $\mathrm{pH}$ of medium}

Figure 5 shows the MCE and protease production by $B$. amyloliquifaciens in the medium, which was adjusted to different initial $\mathrm{pH}$ values ( $\mathrm{pH}$ from 5 to 12 ) and cultivated at $37{ }^{\circ} \mathrm{C}$ with shaking at $120 \mathrm{rpm}$ for $24 \mathrm{~h}$. It was observed that the MCE production reached their maximum $(130 \mathrm{SU} / \mathrm{ml})$ when the initial $\mathrm{pH}$ of medium was adjusted to 6 with maximum MCA/PA (130/945). Further decrease in the initial $\mathrm{pH}$ values resulted in the reduced $\mathrm{MCE}$ and protease production. However, further increase in $\mathrm{pH}$ of medium decreased MCA production, but protease activity increased upto $\mathrm{pH}$ 8.0, and thereafter, decrease was observed.

\section{Production of milk-clotting activity affected by cultivation temperature}

It is known that the production of MCE by microorganisms was profoundly affected by cultivation temperature. The effect of cultivation temperature on MCE production by $B$. amyloliquifaciens in the medium was studied at pH 6 and at various temperatures $\left(25-60{ }^{\circ} \mathrm{C}\right.$, at $5{ }^{\circ} \mathrm{C}$ increments) (Fig. 6). Although strain could grow in broad temperature range $\left(25-50{ }^{\circ} \mathrm{C}\right)$, but maximum MCA was detected at $30^{\circ} \mathrm{C}$ with low proteolytic activity $(830 \mu \mathrm{g} / \mathrm{ml} / \mathrm{min})$ after cultivation for $24 \mathrm{~h}$ with shaking at $120 \mathrm{rpm}$. Increasing or lowering the cultivation temperature resulted in the reduction of the MCE production by test organism, and the MCA disappeared completely at $50{ }^{\circ} \mathrm{C}$.

\section{Effect of inoculum size on production of milk-clotting enzyme}

An inoculum size of $1 \%$ is found to be optimal for MCE production by $B$. amyloliquifaciens with $142 \mathrm{SU} / \mathrm{ml}$ and maximum MCA/PA ratio (Fig. 7). Further increase in inoculum size resulted in decrease in MCA production. 


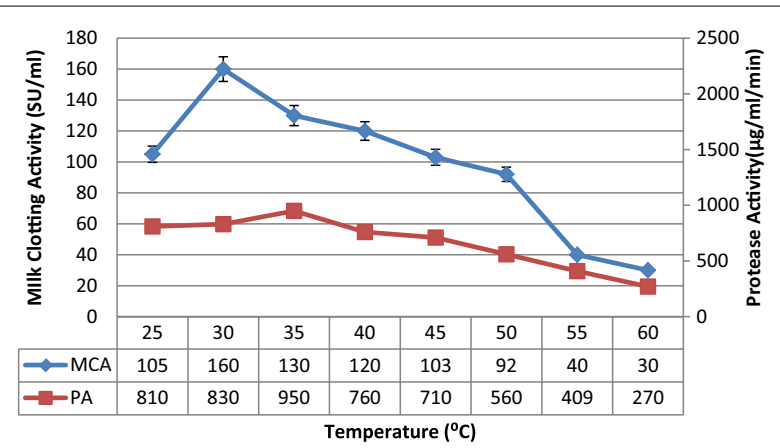

Fig. 6 Milk-clotting activity produced by Bacillus amyloliquifaciens affected by fermentation temperature in $24 \mathrm{~h}$ of cultivation

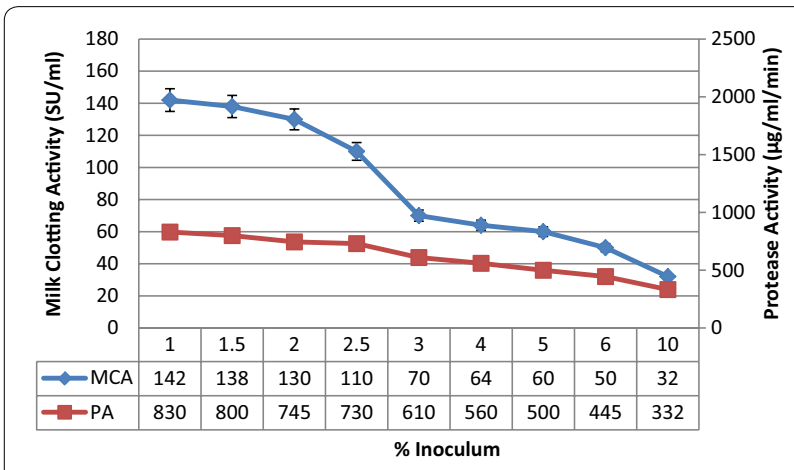

Fig. 7 Milk-clotting activity produced by Bacillus amyloliquifaciens affected by inoculum size in $24 \mathrm{~h}$ of cultivation

\section{Discussion}

Many bacteria, especially several species belonging to Bacillus, are known to produce variety of extracellular enzymes, and they have a wide range of industrial applications (Wim 2006). Bacteria belonging to Bacillus, such as B. licheniformis, B. subtilis and B. subtilis natto, have been suggested as promising microbial rennet producers (Dutt et al. 2009; Shieh et al. 2009; Ding et al. 2011; Zhang et al. 2013). In this study, we characterized a strain of B. amyloliquifaciens capable of producing milkclotting enzyme and proteolytic activity (Guleria et al. 2014). Milk-clotting enzymes are invariably accompanied by proteolytic activity. In a program for the screening of bacteria for MCA, it was of interest to determine their proteolytic activity (exocellular). According to the morphological, biochemical, and $16 \mathrm{~S}$ rDNA sequencing, isolate was identified as a strain of $B$. amyloliquifaciens (Table 1; Fig. 1).

To find out an adequate substitute to commercial rennet, in the present work, optimization of such culture conditions and medium components was done, where intense milk-clotting activity and low proteolytic activity were observed. From results shown in Fig. 2, on the basis of high MCA/PA ratio, sucrose was considered as best $\mathrm{C}$-source. The results shown here are in agreement with those found for many other microorganisms in that sucrose $(0.5 \%)$ was the most favorable carbon source for Bacillus subtillus natto (Shieh et al. 2009) and Penicillium oxalicum (Hashem 1999) to produce MCE. Glucose, on the other hand, was not favorable for P. oxalicum (Hashem 1999), and did not influence the enzyme production for Nocardiopsis sp. (Cavalcanti et al. 2005). Instead of glucose and sucrose, Odeniyi et al. (2009) found galactose, lactose, and trehlose as best C-sources for MCE production, whereas Merheb-Dini et al. (2010, 2012) used wheat bran as substrate.

Addition of organic nitrogen sources to the medium showed maximum production with soyabean $(96 \mathrm{SU} / \mathrm{ml})$ followed by tryptone $(82 \mathrm{SU} / \mathrm{ml})$ and peptone $(75 \mathrm{SU} /$ $\mathrm{ml})$. However, the addition of inorganic nitrogen sources, such as ammonium chloride and urea (46 and $30 \mathrm{SU} /$ $\mathrm{ml}$ ), respectively, causes a decrease in milk-clotting activity (Fig. 3). Our results are similar to the earlier reports that showed that inorganic nitrogen sources (sodium nitrate, urea, and ammonium nitrate) gave poor production of MCE, but organic nitrogen sources (wheat bran, wheat four, and skim milk powder) favored good enzyme yield (Thakur et al. 1990; Merheb-Dini et al. 2010, 2012; Alecrim et al. 2015). Depending on the peptide nature and level, MCE synthesis may be induced or repressed by proteinaceous materials. It is noted that the nitrogen sources used in the seed culture in this study was also complex organic compound (soyabean) that might explain the ample MCE production by $B$. amyloliquifaciens.

Time course for the MCA production by B. amyloliquifaciens was studied in the liquid-state fermentation. The maximum enzyme production and MCA/PA ratio were obtained after $24 \mathrm{~h}$ of incubation, and it is obvious that prolonged incubation time after $24 \mathrm{~h}$ decreases the MCA production (Fig. 4). However, the reason(s) for the decline remains to be investigated. Although similar results of fast MCE production by B. subtilis (natto), Takahashi and Thermomucor indicae were observed by Wu et al. (2013) and Merheb-Dini et al. (2012). However, optimal production of Nocardiopsis sp. and Mucor circinelloides was observed after $56 \mathrm{~h}$ and 5 days, respectively (Thakur et al. 1990).

Effect of initial $\mathrm{pH}$ of the medium on the MCE production has been illustrated. The MCE production by Bacillus licheniformis, A. rouxii (Yu and Chou 2005) and Bacillus amyloliquefaciens (Zhang et al. 2013) is the highest in the medium with an initial $\mathrm{pH}$ value at 7 and 7.57 , respectively. While maximum MCE production by Fusarium subglutinans (Ghareib et al. 2001) and Bacillus subtilis (Dutt et al. 2009) were reported with an initial 
$\mathrm{pH}$ of 6.0. It was clear from Fig. 5 that B. amyloliquifaciens SP1 may also capable of producing alkaline protease $(1690 \mu \mathrm{g} / \mathrm{ml} / \mathrm{min}$ at $\mathrm{pH} 8.0)$, but at $\mathrm{pH} 6.0$, higher amount of MCA/PA was observed. The observations shown in this study along with the reports of previous investigators suggest that the optimal initial $\mathrm{pH}$, i.e., 6.0 of the medium for MCE production may vary depending on the culture medium and the test organism (Fig. 5).

The enzyme production by $B$. amyloliquifaciens at $25-50{ }^{\circ} \mathrm{C}$ temperature range revealed that there is an increase in MCA production from $25^{\circ} \mathrm{C}(105 \mathrm{SU} / \mathrm{ml})$ to $30{ }^{\circ} \mathrm{C}(160 \mathrm{SU} / \mathrm{ml})$ with corresponding increase in MCA/ PA ratio (Fig. 6). The optimal MCE production temperature found in the present study is in contrast with those of previous reports in that it was $30{ }^{\circ} \mathrm{C}$ for A. rouxii (Yu and Chou 2005), Mucor J20 (Hosoi and Kiuchi 2004) and $37^{\circ} \mathrm{C}$ for B. amyloliquifaciens (Zhang et al. 2013), while it was $42{ }^{\circ} \mathrm{C}$ for $M$. miehei (Thakur et al. 1990), and sudden decrease was observed with further increase in temperature.

Inoculum size is the key factor that strongly influences microbial growth and activity in submerged fermentation. The results represented in Fig. 7 showed that the optimum MCE production (142 SU/ml) with low proteolysis, i.e., $830 \mu \mathrm{g} / \mathrm{ml} / \mathrm{min}$, is obtained when the inoculum size is $1 \%$. However, optimal MCE production of Bacillus subtilis was observed with $3 \%$ inoculum size (Dutt et al. 2009). A decrease in enzyme production was noted when the inoculum size increased, which is due to the shortage of nutrients available for the larger biomass and faster growth of the culture (Sathya et al. 2009).

\section{Conclusion}

After exploring rhizosphere of apple trees of trans Himalayas, 76 protease producing isolates from RS and ER of apple trees were obtained. In conclusion, this investigation revealed a potential MCA producer, i.e., $B$. amyloliquifaciens, and its operational and nutritional factors have been studied for the production of MCE. High MCA (142 SU/ml) and MCA/PA ratio can be obtained when the bacteria was cultivated in the medium containing sucrose as $\mathrm{C}$-source $(0.1 \%)$ and soyabean as $\mathrm{N}$-source $(0.25 \%)$ at $\mathrm{pH} 6.0$ and $30{ }^{\circ} \mathrm{C}$ for $24 \mathrm{~h}$ at $1 \%$ inoculum size. These optimized conditions resulted in a 1.9 -fold increase in the production of the milk-clotting enzyme. Hence, this high amount of MCA and MCA/PA ratio insures its usefulness as new source of milk coagulant for cheese making.

\section{Authors' contributions}

SG carried out all the experimental work. AW and AC helped in the analysis of data. CKS guided all research work and participated in the design of study. All authors read and approved the final manuscript.

\begin{abstract}
Author details
${ }^{1}$ Department of Microbiology, Kurukshetra University, Kurukshetra, Haryana, India. ${ }^{2}$ Department of Microbiology, DAV University, Jalandhar, Punjab 144012 India. ${ }^{3}$ Department of Basic Sciences (Microbiology Section), Dr. Y. S. Parmar University of Horticulture and Forestry, Nauni, Solan, HP 173230, India.
\end{abstract}

\section{Acknowledgements}

Authors are grateful to INSPIRE Program, Department of Science and Technology, Ministry of Science and Technology, Government of India, for providing fellowship and facilities.

\section{Competing interests}

The authors declare that they have no competing interests.

Received: 28 December 2015 Accepted: 27 May 2016

Published online: 07 June 2016

\section{References}

Alecrim MM, Palheta RA, Teixeira MFS, Oliveira IMA (2015) Milk-clotting enzymes produced by Aspergillus flavo furcatis strains on Amazonic fruit waste. Int J Food Sci Technol 50:151-157

Altschul SF, Thomas LM, Alejandro AS, Jinghui Z, Zheng Z, Webb M, David JL (1997) Gapped BLAST and PSIBLAST: a new generation of protein database search programs. Nucleic Acids Res 25:3389-3402

Arima K, Yu J, Iwasaki S (1970) Milk-clotting enzyme from Mucor pusillus var. Lindt. Methods Enzymol 19:446-459

Cavalcanti MTH, Martinez CR, Furtaso VC, Neto BB, Teixeira MFS, Lima Filho JL, Porto ALF (2005) Milk-clotting protease production by Nocardiopsis sp. in an inexpensive medium. World J Microbiol Biotechnol 21:151-154

Corpet F (1988) Multiple sequence alignment with hierarchial clustering. Nucleic Acids Res 16:10881-10890

Ding ZY, Liu SP, Gu ZH, Zhang L, Zhang KC, Shi GY (2011) Production of milkclotting enzyme by Bacillus subtilis B1 from wheat bran. Afr J Biotechnol 10:9370-9378

Dutt K, Gupta P, Saran S, Misra S, Saxena RK (2009) Production of milk-clotting protease from Bacillus subtilis. Appl Biochem Biotechnol 158(3):761-772

Enyard CC (2008) Sigma's non-specific protease activity assay-casein as substrate. J Vis Exp 19:899

Ghareib M, Hamdy HS, Khali AA (2001) Production of intracellular milk-clotting enzyme in submerged cultures of Fusarium subglutinans. Acta Microbiol Pol 50:139-147

Guleria S, Walia A, Chauhan A, Shirkot CK (2014) Genotypic and phenotypic diversity analysis of alkalophilic proteolytic Bacillus sp. associated with rhizosphere of apple trees in trans Himalayan region of Himachal Pradesh. Proc Natl Acad Sci India Sect B Biol Sci. doi:10.1007/ s40011-014-0447-z

Hashem AM (1999) Optimization of milk-clotting enzyme productivity by Penicillium oxalicum. Bioresour Technol 70:203-207

Hashem AM (2000) Purification and properties of a milk-clotting enzyme produced by Penicillium oxalicum. Bioresour Technol 75:219-222

He XL, Ren FZ, Guo HY, Zhang WB, Song X, Gan BZ (2011) Purification and properties of a milk-clotting enzyme produced by Bacillus amyloliquefaciens D4. Korean J Chem Eng 28:203-208

Higgins D, Thompson J, Gibson T, Thompson JD, Higgins DG, Gibson TJ (1994) CLUSTAL W: improving the sensitivity of progressive multiple sequence alignment through sequence weighting, position-specific gap penalties and weight matrix choice. Nucleic Acids Res 22:4673-4680

Hosoi T, Kiuchi K (2004) Production and probiotic effects of natto. In: Ricca E, Henriques AO, Cutting S (eds) Bacterial spore formers: probiotics and emerging applications. Horizon Bioscience, Norwich

Kumar S, Sharma NS, Saharan MR, Singh R (2005) Extracellular acid protease from Rhizopus oryzae: purification and characterization. Process Biochem 40:1701-1705

Li Y, Liang S, Zhi D, Chen P, SU F, Li H (2012) Purification and characterization of Bacillus subtilis milk-clotting enzyme from Tibet Plateau and its potential use in yak dairy industry. Eur Food Res Technol 234:733-741 
Merheb-Dini C, Gomes E, Boscolo M, da Silva R (2010) Production and characterization of a milk clotting protease in the crude enzymatic extract from the newly isolated Thermomucor indicae-seudaticae N31 (Milk clotting protease from the newly isolated Thermomucor indicae-seudaticae N31). Food Chem 120:87-93

Merheb-Dini C, Garcia GAC, Penna ALB, Gomes E, da Silva R (2012) Use of a new milk-clotting protease from Thermomucor indicae-seudaticae N31 as coagulant and changes during ripening of Prato cheese. Food Chem 130:850-865

Nouani A, Moulti-Mati F, Belbraouet S, Bellal MM (2011) Purification and characterization of a milk-clotting protease from Mucor pusillus: method comparison. Afr J Biotechnol 10:1655-1665

Odeniyi OA, Onilude AA, Ayodele MA (2009) Growth and substrate utilization patterns of a Rhizopus stolonifer strain isolated from depolymerising rice husk. World Appl Sci J 6(5):595-599

Page RDM (1996) TREEVIEW: an application to display phylogenetic trees on personal computers. Comput Appl Biosci 12:357-358

Sambrook J, Russel DW (2001) Molecular cloning: a laboratory manual. Cold spring Harbor Laboratory, New York

Sambrook J, Fritsch EF, Maniatis T (1989) Molecular cloning: a laboratory manual. Cold Spring Harbor Laboratory, New York

Sathya R, Pradeep BV, Angayarkanni J, Palaniswamy M (2009) Production of milk clotting protease by a local isolate of Mucor circinelloides under SSF using agro-industrial wastes. Biotech Bioprocess Eng 14:788-794

Shieh CJ, Phan TL, Shih IL (2009) Milk-clotting enzymes produced by culture of Bacillus subtilis natto. Biochem Eng J 43:85-91

Silveira GG, Oliveira GM, Riberieo EJ, Monti R, Contiero J (2005) Microbial rennet produced by Mucor miehei in solid-state and submerged fermentation. Brazil Arch Biol Technol 48:931-937

Sneath PHA (1994) Endospore forming gram positive rods and cocci. In: Hensyl WM (ed) Bergey's manual of systematic bacteriology, 9th edn. Williams and Wilkins, Philadelphia
Thakur MS, Karanth NG, Nand K (1990) Production of fungal rennet by Mucor miehei using solid state fermentation. Appl Microbiol Biotechnol 32:409-413

Tubesha ZA, Delaimy KSA (2003) Renin like milk coagulant enzyme produced by a local isolate of Mucor. Int J Dairy Technol 56:237-341

Walia A, Mehta P, Chauhan A, Shirkot CK (2013) Optimization of cellulasefree xylanase production by alkalophilic Cellulosimicrobium sp. CKMX1 in solid-state fermentation of apple pomace using central composite design and response surface methodology. Ann Microbiol 63:187-198

Wim JQ (2006) Bacterial enzymes. Prokaryotes 1:777-796

Wu FC, Chang CW, Shih IL (2013) Optimization of the production and characterization of milk clotting enzymes by Bacillus subtilis natto. SpringerPlus 2:33

Yu PJ, Chou CC (2005) Factors affecting the growth and production of milkclotting enzymes by Amylomyces rouxii in rice liquid medium. Food Technol Biotechnol 43:283-288

Zhang ZG, Wang CZ, Yao ZY, Zhao JF, Lu FX, Yu GM, Lan WJ, Lu ZX (2011) Isolation and identification of a fungal strain QY229 producing milk-clotting enzyme. Eur Food Res Technol 232:861-866

Zhang W, He X, Liu H, Guo H, Ren F, Wen P (2013) Statistical optimization of culture conditions for milk-clotting enzyme production by Bacillus amyloliquefaciens using wheat bran-an agro-industry waste. Indian J Microbiol 53(4):492-495

\section{Submit your manuscript to a SpringerOpen ${ }^{\odot}$ journal and benefit from:}

- Convenient online submission

Rigorous peer review

- Immediate publication on acceptance

- Open access: articles freely available online

- High visibility within the field

- Retaining the copyright to your article

Submit your next manuscript at springeropen.com 